See discussions, stats, and author profiles for this publication at: https://www.researchgate.net/publication/323110285

\title{
LITERASI MATEMATIS DALAM PEMBELAJARAN BERBASIS MASALAH
}

Conference Paper · February 2018

CITATIONS

0

1 author:

Pe) Ary Kiswanto Kenedi

Situs Resmi Universitas Negeri Padang

4 PUBLICATIONS 2 CITATIONS

SEE PROFILE
READS

476

Some of the authors of this publication are also working on these related projects:

Project LITERASI MATEMATIS DALAM PEMBELAJARAN BERBASIS MASALAH View project 
PR OASIDING

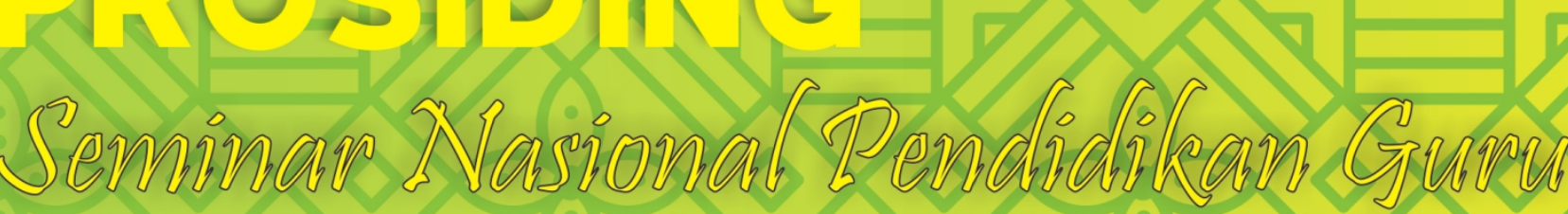

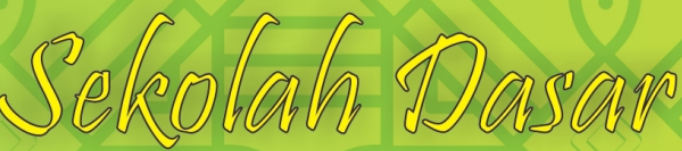

Pembelajaran Literadi-Liniad Disiblin Temu Ke-5D-an
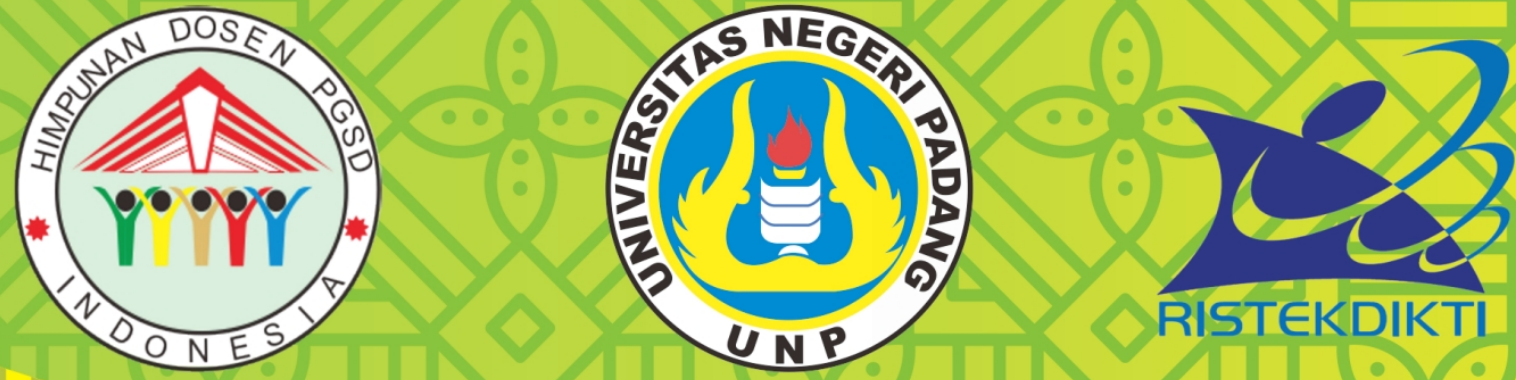

Grand Rocky Plaza Hotel, Bukittinggi 4, 5, dan 6 September 2017

Kerjasama:

Pendidikan Guru Sekolah Dasar

Fakultas Ilmu Pendidikan

Universitas Negeri Padang

dengan

Himpunan Dosen Pendidikan Guru Sekolah Dasar Indonesia 2017 


\title{
Prosiding \\ Seminar Nasional \\ Pendidikan Guru Sekolah Dasar
}

\section{Pembelajaran Literasi \\ Lintas Disiplin Ilmu Ke-SD-an}

\author{
Editor: \\ Prof. Dr. Hasanuddin WS., M.Hum. \\ Dr. Taufina, M.Pd. \\ Chandra, S.Pd., M.Pd. \\ Yesi Anita, S.Pd., M.Pd.
}

Tempat Pelaksanaan:

Grand Rocky Hotel Bukittinggi, Sumatera Barat, Indonesia

Tanggal Pelaksanaan:

4, 5, dan 6 September 2017
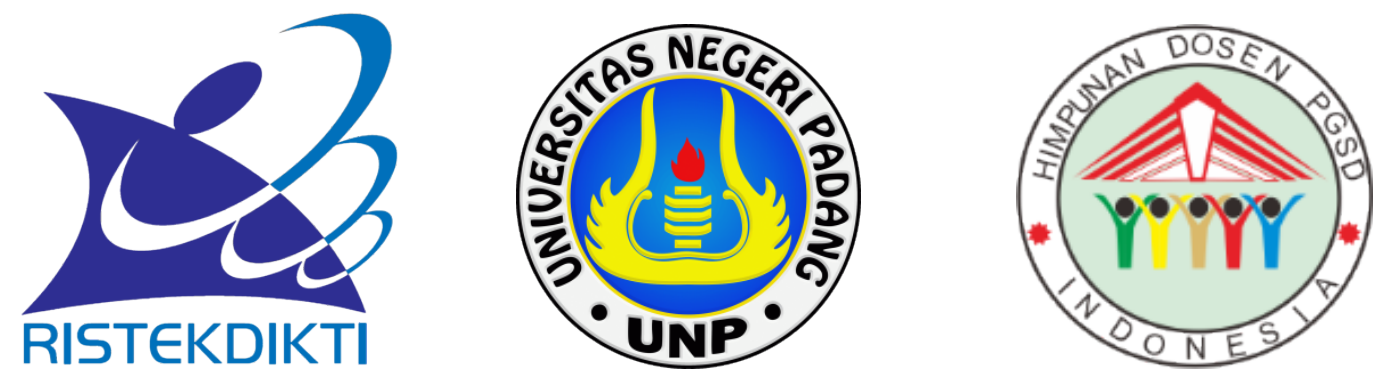

Penerbit: Jurusan PGSD FIP UNP 
Prosiding Seminar Nasional Pendidikan Guru Sekolah Dasar

dengan Tema "Pembelajaran Literasi Lintas Disiplin Ilmu Ke-SD-an"

ISBN: 978-602-619994-0-4

$\begin{array}{ll}\text { Susunan Panitia Seminar Nasional Pendidikan Guru Sekolah Dasar } \\ \text { Pengarah } & \text { : Dr. Alwen Bentri, M.Pd. } \\ \text { Penanggung Jawab } & \text { : Drs. Muhammadi, M.Si. } \\ \text { Ketua Pelaksana } & \text { : Dr. Taufina, M.Pd. } \\ \text { Wakil } & \text { : Drs. Syafri Ahmad, M.Pd. } \\ \text { Sekretaris } & \text { : Dr. Desyandri, M.Pd. } \\ \text { Bendahara } & \text { : Dra. Masniladevi, S. Pd., M.Pd. }\end{array}$

Koordinator Seksi Sekretariatan:

Yullys Helsa, M.Pd.

Anggota:

1. Sherlyane Hendri, S.Pd., M.Pd.

2. Rizky Amelia, S.Pd., M.Pd.

3. Hasmai Bungsu Ladiva, S.Pd., M.Pd.

4. Khairawati, A.Md.

Koordinator Seksi Acara:

Ary Kiswanto Kenedi, S.Pd., M.Pd.

Anggota:

Rafhi Febrian Putera, S.Pd., M.Pd.

Koordinator Seksi Tamu:

Drs. Zainal Abidin, M.Pd.

Anggota:

1. Dra. Yetti Ariani, M.Pd.

2. Dra. Syamsu Arlis, M.Pd.

3. Dra. Hamimah, M.Pd.

4. Dra. Mayarnimar, M.Pd.

5. Drs. Mansur, M.Pd.

Koordinator Seksi Humas dan Publikasi:

Drs. Zuardi, M.Si.

Anggota:

1. Dra. Silvinia, M.Ed.

2. Drs. Nasrul, M.Pd.

\section{Reviewer:}

1. Dr. Yanti Fitria, M.Pd.

2. Dr. Darnis Arief, M.Pd.

3. Dra. Elfia Sukma, M.Pd.

4. Melva Zainil, S.T., M.Pd.

Koordinator Seksi Perlengkapan dan Transportasi:

Drs. Yunisrul, M.Pd.

Anggota:

1. Drs. Arwin, M.Pd.

2. M. Habibi, M.Pd.

3. Asmar

Koordinator Seksi Konsumsi:

Dra. Rifda Eliasni, M.Pd.

Anggota:

1. Dra. Zuryanti, M.Pd.

2. Dra. Reinita, M.Pd.

3. Dra. Harni, M.Pd.

Koordinator Seksi Prosiding:

Dr. Yanti Fitria, M.Pd.

Anggota:

1. Dr. Darnis Arief, M.Pd.

2. Melva Zainil, S.T., M.Pd.

3. Dra. Elfia Sukma, M.Pd.

4. Nur Azmi Alwi, S.S., M.Pd.

5. Chandra, S.Pd., M.Pd.

6. Yesi Anita, S.Pd., M.Pd.

Koordinator Seksi Dokumentasi: Muhariman

Anggota:

Irzaldi, S.Pd.

\section{Editor:}
1. Prof. Dr. Hasanuddin WS., M.Hum.
2. Dr. Taufina, M.Pd.

5. Nur Azmi Alwi, S.Pd., M.Pd.

6. Chandra, S.Pd., M.Pd.

7. Yesi Anita, S.Pd., M.Pd.

Penyunting:

Dr. Yanti Fitria, M.Pd.

Disain Sampul:

Ucok Eka Saputra

\section{Penerbit: Jurusan PGSD FIP UNP}

(C) Hak cipta terpelihara dan dilindungi Undang-undang No. 19 Tahun 2002

Tidak dibenarkan menerbitkan ulang bagian atau keseluruhan isi buku ini dalam bentuk apapun juga sebelum mendapat izin tertulis dari Penerbit 


\section{KATA PENGANTAR}

Assalammualaikum Wr.Wb.

Puji syukur kita panjatkan kehadirat Allah SWT. karena perkenan-Nya kita dapat melaksanakan pertemuan ilmiah berupa musyawarah wilayah Himpunan Dosen Pendidikan Guru Sekolah Dasar Indonesia dan Seminar Nasional dengan tema "Literasi Lintas Disiplin Ilmu Ke-SD-an" yang dalam pelaksanaannya bekerjasama dengan Jurusan Pendidikan Guru Sekolah Dasar Fakultas Ilmu Pendidikan Universitas Negeri Padang, dilaksanakan di Rocky Plaza Hotel Bukittinggi Sumatera Barat pada tanggal 4, 5, dan 6 September 2017.

Pertemuan ilmiah Musyawarah Wilayah II Himpunan Dosen Pendidikan Guru Sekolah Dasar Indonesia bertujuan mempererat hubungan baik dan membentuk pengurus wilayah Sumatera atau wilayah II HDPGSDI demi terlaksananya kelancaran aktivitas kependidikan serta dilaksanakannya seminar nasional yang berkonsepkan literasi demi terwujudnya pemahaman yang tinggi dalam berbagai disiplin ilmu.

Besar harapan dalam pertemuan musyawarah wilayah HDPGSDI dan seminar nasional ini dapat mencapai tujuan utama dan dapat menyampaikan informasi literasi lintas disiplin ilmu ke-SD-an dalam upaya meningkatkan kecerdasan majemuk dan menjawab tantangan dunia pendidikan. Semoga lahir komitmen tinggi kepengurusan wilayah Sumatera HDPGSDI dalam memajukan pendidikan dasar.

Akhirnya, semoga prosiding hasil musyawarah wilayah Sumatera HDPGSDI dan Seminar Nasional ini mencapai tujuannya dalam menghasilkan solusi dari permasalahan rendahnya literasi Indonesia serta memberikan masukan berarti demi kemajuan pendidikan dasar.

Wassalam,

Editor 


\section{DAFTAR ISI}

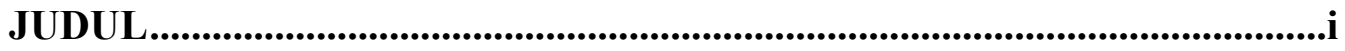

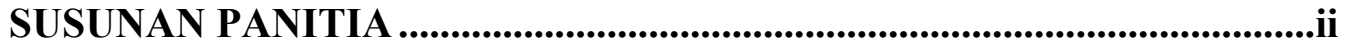

KATA PENGANTAR .......................................................................................ii

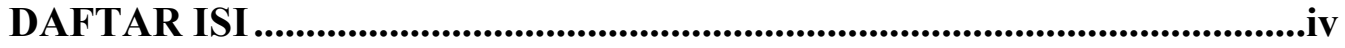

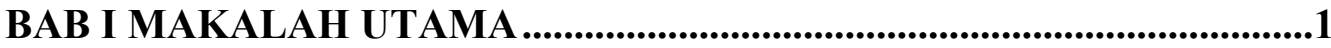

A. Inovasi Media Pembelajaran IPS SD Berbasis IT dalam Mendukung Gerakan Literasi oleh Yalvema Miaz .......................1

B. Peran Warga Sekolah dalam Pembudayaan Nilai-nilai Edukatif Lagu-lagu Minang Melalui Gerakan Literasi di Sekolah Dasar

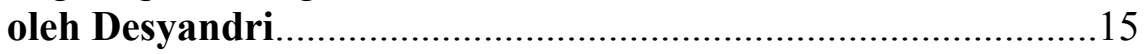

C. Pembelajaran Literasi Sains untuk Level Dasar

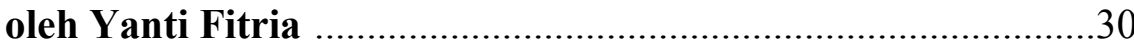

D. Pengembangan Literasi Menulis Prosa Narasi Menggunakan Buku Kerja Siswa untuk Sekolah Dasar oleh Darnis Arief .........41

E. Meningkatkan Kemampuan Literasi Matematis Siswa SD melalui Teknologi IT oleh Yetti Ariani ......................................52

BAB II PEMBELAJARAN LITERASI SAINS SD...............................65

A. Pembelajaran IPA dengan Pendekatan Saintifik dan Literasi Sains oleh Asep Sukenda Egok (STKIP-PGRI

Buluklinggau)

B. Upaya Peningkatan Kualitas Literasi Sains dalam Proses

Pembelajaran oleh Syamsu Arlis (PGSD FIP UNP)

C. Pembelajaran Berbasis Masalah sebagai Upaya Peningkatan Literasi

Sains oleh Zuryanti (PGSD FIP UNP)

D. Pengembangan Media Pembelajaran Ilmu Pengetahuan Alam Berbasis Komputer Menggunakan Macromedia Flash 8 di Sekolah Dasar oleh Marzuki dan Sutiyanto (Universitas Tanjungpura)

E. Penggunaan Media Pembelajaran dapat Meningkatkan Hasil Belajar Siswa pada Materi Rangka Tubuh Manusia Mata Pelajaran IPA di Kelas IV SD oleh Rohmaddi (Sekolah Dasar 03 Margodadi, Tumijajar, Tulang Bawang Barat, Lampung)

F. Meningkatkan Kemampuan Berpikir Kritis Siswa Melalui Model Pembelajaran Siklus Belajar 5e Pada Mata Pelajaran IPA Kelas IVA SDN 215 Inpres To'ra'da' Kecamatan Makale Kabupaten Tana Toraja oleh Susanna Vonny N. Rante (Program Studi PGSD, FKIP, Universitas Kristen Indonesia Toraja)

G. Analisis Minat Baca Siswa Kelas 3 pada Pembelajaran IPA yang Menggunakan Media Komik S2 oleh Cicilia Ika Rahayu Nita dan Nur Huda (Universitas Kanjuruhan Malang). 
H. Pengembangan Education Game Berbasis Flash (EGBF) Belajar IPA pada Siswa Sekolah Dasar oleh Para Mitta Purbosari (PGSD, FKIP, Universitas Veteran Bangun Nusantara Sukoharjo).

I. Membangun Literasi Sains Siswa dalam Pembelajaran IPA Melalui Science Edutainment untuk Menciptakan Suasana AJEL (Active Joyfull and Effective Learning) di Sekolah Dasar oleh Eni Marta, Pariang Sonang Siregar, dan Lia Wardani (Pendidikan Guru Sekolah Dasar, STKIP Rokania)

BAB III PEMBELAJARAN LITERASI NUMERASI SD.

A. Literasi Matematis dalam Pembelajaran Berbasis Masalah oleh Ary Kiswanto Kenedi dan Yullys Helsa (PGSD FIP UNP)

B. Pengaruh Penggunaan Pendekatan Konstruktivisme Terhadap Penguasaan Konsep Perkalian Pecahan di Sekolah Dasar oleh Syafri Ahmad (PGSD FIP UNP)

C. Analisis Keterampilan Berpikir Tingkat Tinggi Siswa SD IT

Adzkia oleh Muhammad Anwar (Universitas Negeri Padang), Vivi Puspita (Sekolah Tinggi Keguruan dan Ilmu Pendidikan (STKIP) Adzkia Indonesia)

D. Penerapan Pembelajaran Aktif Tipe Kuis Tim dalam Pembelajaran Matematika Siswa Kelas V SDN 46 Kuranji oleh Sherlyane Hendri (PGSD FIP UNP)

\section{BAB VI PEMBELAJARAN LITERASI BUDAYA DAN} KEWARGANEGARAAN SD

A. Analisis Literasi Budaya Rabab dalam Mengungkap Nilainilai Moral bagi Siswa SD oleh Yesi Anita (PGSD FIP UNP).

B. Peningkatan Penerapan Nilai Karakter Bangsa Menggunakan Pendekatan VCT MODEL Daftar Berorientasi Reading Literacy pada Pembelajaran Pkn Siswa Kelas IV Sekolah Dasar oleh Reinita (PGSD FIP UNP)

C. Literasi Politik dalam Pembelajaran Pkn Di Sekolah Dasar oleh Rafhi Febryan Putera (PGSD FIP UNP)

D. Metode Pembelajaran Simulasi dalam Pembelajaran Keterampilan Literasi Informasi IPS di Kelas Tiggi Sekolah Dasar oleh Hamimah (PGSD FIP UNP)

E. Meretas Nilai-nilai Keunggulan di Sekolah Dasar oleh Endang Poerwanti (PGSD FKIP UMM)

F. Implementasi Buku Ajar IPS Berbasis Metode Inkuiri Untuk Meningkatkan Hasil Belajar Siswa Kelas IV SD oleh Vivin Nurul Hidayah, Alben Ambarita, dan Pujiati (Universitas Lampung) 
G. Pembelajaran Ilmu Pengetahuan Sosial dengan Model Pembelajaran Kooperatif Tipe Numbered Head Together di

Sekolah Dasar oleh Zainal Abidin dan Retno Wulan Dari ......287

H. Perbedaan Keterampilan Siaga Bencana Pada Pelaksanaan Ekstrakurikuler Pramuka Siaga Bencana Secara Terintegrasi dan Berlapis pada Siswa SD Negeri di Kota Bengkulu oleh Endang Widi Winarni dan Wachidi (Universitas Bengkulu).

I. Peran Guru dalam Membentuk Sikap Sosial Siswa Melalui Mata Pelajaran PKN di Kelas IV SDN 2 Telaga Biru Kabupaten Gorontalo oleh Hakop Walangadi (PGSD FIP Universitas Negeri Gorontalo).

J. Pengembangan dan Validasi Angket My Classroom Inventory (MCI) Versi Bahasa Indonesia oleh Irwan Koto (Program Studi Pasca Sarjana Pendidikan Dasar, Universitas Bengkulu)

K. Pengembangan Evaluasi Berbasis Taksonomi Bloom Dua Dimensi pada Mata Pelajaran IPS Kelas IV Sekolah Dasar oleh Rizki Ananda ${ }^{1}$, Fadhilaturrahmi (PGSD Universitas Pahlawan Tuanku Tambusai)

L. Efektivitas Model Bahan Ajar Mulok Berbasis Cerita Rakyat untuk Pendidikan Karakter di SD oleh Abdul Muktadir (PGSD FKIP Universitas Bengkulu)

M. Inspirasi dan Kreasi Gambar dengan Teknik Cetak bagi Guru SD oleh Harni (PGSD FIP UNP)

BAB V PEMBELAJARAN LITERASI BAHASA SD

A. Perwujudan Berpikir Kritis Siswa dalam Implementasi Literasi Membaca Berbasis Strategi The Big Questions and Bookmark Organizers di Sekoah Dasar oleh Chandra dan Sri Amerta (PGSD FIP UNP)

B. Penerapan Pendekatan Integratif untuk Meningkatkan

Kemampuan Membaca Pemahaman Siswa Kelas IV SDN 2 Tikala Kabupaten Toraja Utara oleh Harmelia Tulak (PGSD FKIP Universitas Kristen Indonesia Toraja)

C. Pengembangan Model Writing Workshop Berbantuan Audio Visual untuk Meningkatkan Keterampilan Menulis Narasi Siswa Sekolah Dasar oleh Hartati (PGSD, Universitas Negeri Semarang)

D. Peningkatan Keterampilan Literasi Membaca Pemahaman dengan Menggunakan Metode Generating Interacting Schemata and Text (GIST) di Sekolah Dasar oleh Mayarnimar dan Yulia Rahmi (PGSD FIP UNP). 
E. Perbedaan Kemampuan Siswa Kelas IV Menulis Narasi Melalui Pembelajaran Menggunakan Gambar Seri dan Pembelajaran Konvensional di SDN Sedarum 1 Pasuruan oleh Dimyati dan Tyanto Zakariyah Faruq

BAB VI PEMBELAJARAN LITERASI TEMATIK 432

A. Hubungan Penguasaan Kompetensi terhadap Kinerja Guru Pasca Sertifikasi di Sekolah Dasar oleh Miftha Indasari, Pranita Yuliana, dan Febriani Rotua Manullang

B. Pengaruh Pembelajaran Tematik Berbasis Potensi Daerah terhadap Pengetahuan Siswa Sekolah Dasar tentang Kepahlawanan oleh Sri Dadi, Endang Widi Winarni, dan Herman Lusa (Universitas Bengkulu)

C. Kendala Guru dalam Pelaksanaan Pembelajaran Tematik Terpadu di Kelas Iv Sdn No 42/Iv Kota Jambi oleh Maryono, Desternelli, Suci Hayati, dan Leila Listiyani (PGSD FKIP Universitas Jambi)

D. Pengembangan Media Pembelajaran Tematik-Integratif pada Tema Menghargai Jasa Pahlawan dengan Tokoh Nyi Ageng Serang di Kelas IV Sekolah Dasar oleh Faridl Musyadad, Atika Dwi Evitasari, dan Anita Dewi Astuti (IKIP PGRI Wates Yogyakarta)

E. Identifikasi Tema, Subtema, Kompetensi Dasar dan Indikator Sikap Peduli Lingkungan dalam Pembelajaran Tematik di Sekolah Dasar oleh Victoria Karjiyati dan Hasnawati

F. Permasalahan Guru dalam Menerapkan Penilaian Autentik di Sekolah Dasar oleh Rusmin Husain dan Elvi (PGSD FIP Universitas Negeri Gorontalo).

G. Penerapan Model Problem Based Learning dalam Meningkatkan Proses Pembelajaran Tematik Terpadu di Sekolah Dasar oleh Mulyani Zen (PGSD FIP UNP)

H. Identifikasi Kompetensi Dasar dan Indikator Bahan Ajar Pembelajaran Tematik Berbasis Wilayah di Sekolah Dasar oleh Ansyori Gunawan, Sri Dadi, dan Dwi Anggraini (Universitas Bengkulu) 


\title{
LITERASI MATEMATIS DALAM PEMBELAJARAN BERBASIS MASALAH
}

\author{
Ary Kiswanto Kenedi ${ }^{1}$, Yullys Helsa ${ }^{2}$ \\ Jurusan Pendidikan Guru Sekolah Dasar, Fakultas Ilmu Pendidikan \\ Universitas Negeri Padang \\ arykenedi@gmail.com, yullyshelsa@gmail.com
}

\begin{abstract}
ABSTRAK
Literasi atau melek matematis didefinisikan sebagai kemampuan seseorang individu merumuskan, menggunakan, dan menafsirkan matematika dalam berbagai konteks. Termasuk di dalamnya bernalar secara matematis dan menggunakan konsep, prosedur, fakta, dan alat matematika dalam menjelaskan serta memprediksi fenomena. Komponen utama dalam literasi matematis yaitu memudahkan pemecahan masalah sehari-hari yang sekaligus dapat mengembangkan kemampuan matematikanya. Pembelajaran berbasis masalah merupakan salah satu model pembelajaran yang menyajikan masalah kontekstual yang dapat merangsang kreativitas peserta didik untuk menemukan konsep dan memecahkan masalah dalam kehidupan sehari-hari. Oleh sebab itu adanya kaitan yang erat literasi matematis dalam pembelajaran berbasis masalah.
\end{abstract}

Kata kunci: Literasi matematis, problem based learning

\section{PENDAHULUAN}

Berkembangnya ilmu sain dan tekhnlogi memunculkan sebuah kewajiban bagi peserta didik untuk menguasai ilmu matematika. Matematika adalah sebuah ilmu yang bersifat universal yang melandasi dan berhubungan dengan sains dan tekhnologi yang memliki fungsi dalam berbagai multi disiplin ilmu lainya. Matematika adalah suatu aktivitas mental untuk memahami arti dan hubungan-hubungan serta simbol-simbol kemudian diterapkan pada situasi nyata. Belajar matematika berkaitan dengan apa dan bagaimana menggunakannya dalam membuat keputusan dalam menyelesaikan masalah (Fitri, 2014:18). Maksudnya adalah matematika adalah sebuah ilmu yang dapat digunakan dalam kehidupan sehari-hari. Sedangkan KTSP 2006 menyatakan bahwa tujuan dari pembelajaran matematika yaitu agar siswa memiliki kemampuan: (1) memahami konsep matematika, menjelaskan keterkaitan antar konsep dan mengaplikasikan konsep atau logaritma secara luwes, akurat, efisien, dan tepat dalam pemecahan masalah, (2) menggunakan penalaran pada pola dan sifat, melakukan manipulasi matematika dalam membuat generalisasi, menyusun bukti atau menjelaskan 
gagasan atau pernyataan matematika, (3) memecahkan masalah yang meliputi kemampuan yang meliputi masalah, merancang model matematika, menyelesaikan model dan menafsirkan solusi yang diperolah, (4) mengomunikasikan gagasan dengan simbol, tabel, diagram atau media lain untuk memperjelas masalah, (5) memiliki sikap menghargai kegunaan matematika dalam kehidupan, yaitu memiliki rasa ingin tahu, perhatian, dan minat dalam mempelajari matematika, serta sikap ulet dan percaya diri dalam pemecahan masalah (Putriyani, 2014:1).

UU No. 20 Tahun 2003 mengenai Sistem Pendidikan Nasional Pasal 37 menyatakan dengan tegas bahwa matematika adalah salah satu mata pelajaran yang harus diajarkan kepada siswa pada jenjang pendidikan dasar dan menengah. Hal ini disebabkan matematika merupakan ilmu yang melandasi berbagai jenis disiplin ilmu lainya termasuk ke dalamnya adalah ilmu alam dan ilmu sosial. Tidak hanya ilmu alam dan ilmu sosial yang didasari oleh matematika, tekhnologi pun juga didasari oleh perkembangan ilmu matematika. (Ibrahim dan Suparni, 2008:35). Oleh sebab itu maka di perlukan sebuah upaya untuk mencapai tujuan matematika tersebut.

Dilihat dari tujuan pendidikan matematika disekolah dasar yang dikemukakan olek Kementrian pendidikan yang tertuang pada KTSP 2006 sesuai dengan aspek yang berada pada literasi matematika. OECD sebuah organisasi internasonal untuk kerjasama dan pembangunan ekonomi mendefinisikan "Mathematical literacy is an individual's capacity to formulate, employ and interpret mathematics in a variety of contexts. It includes reasoning mathematically and using mathematical concepts, procedures, facts and tools to describe, explain and predict phenomena. It assists individuals to recognise the role that mathematics plays in the world and to make the well-founded judgements and decisions needed by constructive, engaged and reflective citizens." (OECD, 2015:65). Artinya adalah kemampuan seseorang untuk merumuskan, mempekerjakan dan menafsirkan matematika dalam berbagai bahasa konteks. Ini mencakup penalaran secara matematis dan menggunakan konsep, prosedur, fakta dan alat matematis Menggambarkan, menjelaskan dan memprediksi fenomena. Ini membantu individu untuk mengenali peran yang dimainkan matematika di Dunia dan untuk membuat keputusan dan keputusan yang mapan yang dibutuhkan secara konstruktif, terlibat dan reflektif warga.

Literasi matematis sangat penting pada kehidupan setiap individu, karena berkaitan dengan tugas dan pekerjaan kehidupan dalam sehari-hari. Pemanfaatan literasi matematis tidak hanya sekeder pemahan aritmetik, namun lebih kepada penguasaan 
pemecahan masalah yang membutuhkan penlaran serta harus mammpu menggunakan logika dalm setiap penegambilan keputusan (Linuhung dalam Kusumah, 2011:3).

Oleh sebab itu literasi matematis sudah seharusnya dimiliki oleh setiap orang agar dapat menghadapai semua permasalahan yang dihadapi dalam kehidupan sehari-hari. Namun ada hal yang bertolakbelakang dengan beberapa penelitian yang telah dilaksanakan. Pertama penelitian yang dilakukan oleh lembaga dunia seperti PISA (Program for International Student Asssesment) dan TIMSS (Trends in Interantional Mathematics and Science Studies) yang mengukur tingkat kemampuan literasi membaca, matematika dan sains. Hasil yang ditemukan masih belum memuaskan. PISA bertujuan untuk mengukur tingkat penguasaan keterampilan dan pengetahuan siswa yang berada ppada akhir tahun pendidikan dasar. PISA beranggapan bahwa siswa yang duduk pada akhir tahun pendidikan dasar (15 tahun) telah menguasai keterampilan dan pengetahuan untuk dapat berpartisipasi sebagai anggota masyarakat atau sebagai warga negara yang telah mempu membangun dan bertanggung jawab, (Sugandi, 2013:2). Adapun yang dinilai pada penelitian PISA adalah literasi matematis, literasi membaca dan literasi sain. Untuk TIMSS adaalah studi internasional yang mengukur kemampuan siswa dibidang matematika dan sains. TIMS bertujuan untuk melihat bagaimana kurikulum yang dicanangkan oleh setiap negara diimplementasikan dan capaian siswa khususnya pada bidang matematika dan sains. TIMSS diselenggarakan setiap 4 tahun sekali dan dikoordinasikan oleh IEA (the International Association for the Evaluation of Educational Achievement).

Indonesia mengikuti PISA tahun 2000, 2003, 2006, 2009 dan 2012 dengan hasil yang tidak menunjukkan banyak perubahan pada setiap keikutsertaannya. Pada PISA tahun 2003, dalam bidang matematika, Indonesia berada di peringkat 38 dari 41 negara dengan rataan skor 360. Pada tahun 2006 rataan skor siswa naik menjadi 391 dengan peringkat 50 dari 57 negara. Pada tahun 2009 Indonesia menempati peringkat 61 dari 65 negara dengan rataan turun menjadi 371 sementara rataan skor internasiol adalah 496. Pada tahun 2012 Indonesia berada di peringkat kedua terbawah hanya unggul dari negara Peru dengan skor 375 yaitu berada pada peringkat 62 dari 63 negara yang mengikuti tes. Sedangkan pada tahun 2015 indonesia mendapatkan skor 386 dengan skor rata-rat 490 (PISA, 2015:1). Hasil dari beberapa kali test Indonesia menunjukan bahwa Idonesia masih rendah. Untuk TIMSS 2007, Indonesia berada di peringkat 39 dari 41 negara. Pada tahun 2011, Indonesia berada di peringkat 38 dari 42 negara dengan skor 386 . Pada tahun 2015, Indonesia berada pada peringkat 45 dari 50 negara dngan skor 397, ( Puspendik, 
2015:2). Hal ini juga membuktikan bahwa penelitian yang dilakukan oleh TIMSS menyatakan bahwa Indoenesia masih rendah dalam berliterasi matematika.

Penelitian di dalam negeri pun banyak mengambarkan bahwa kemampuan literasi matematis masih rendah. Aini dalam penelitianya menyatakan bahwa kemampuan literasi matematis siswa SMP masih tergolong rendah, (Aini, 2013:57). Selain itu hasil lain menyatakan bahwa capaian literasi matematis siswa SMA/MA yang menjadi sampel studi ini masih rendah, (Mahdiansyah 2014:467). Hal ini masih membuktikan bahwa penelitian yang dilakukan dalam negeri pun masih rendah. Salah satu upaya yang dapat dilakukan oleh tenaga pendidik untuk meningkatkan kemampuan literasi matematika siswa adalah melakukan inovasi pembelajaran matematika. (Wardono, 2015:94). Salah satu inovasi pembelajaran matematika adalah menggunakan model pembelajaran pada pembelajaran matematika. Model pembelajaran yang bisa digunakan adalah pembelajaran Problem Based Learning. Penelitian yang dilakukan oleh Istiandaru dkk menyatakan bahwa pembelajaran Problem Based Learning efektif dapat meningkatkan kemampuan literasi matematika siswa. Berdasarkan penelitian tersebut penulis ingin mengkaji Problem Based Learning dapat meningkatkan kualitas literasi matematis.

\section{PEMBAHASAN}

Pengertian literasi adalah "an individual's ability to explore, to conjecture, and to reason logically as well as to use variety of mathematical methods effectively to solve problems. By becoming literate, their mathematical power should develop" (NTMC dalam Sari, 2015:714). Dari definisi diatas dapat kita ambil kesimpulan bahwa ada 4 komponen utama didalam literasi matematis dalam pemecahan masalah yaitu mengekplorasi, menghubungkan dan menalar secara logis serta mengunakan metode matematis yang beragam. Komponen utama ini digunakan untuk memudahkan pemecahan masalah sehari-hari yang sekaligus dapat mengembangkan kemampuan matematikanya.

Literasi atau melek matematika didefinisikan sebagai kemampuan seseorang individu merumuskan, menggunakan, dan menafsirkan matematika dalam berbagai konteks. Termasuk di dalamnya bernalar secara matematis dan menggunakan konsep, prosedur, fakta, dan alat matematika dalam menjelaskan serta memprediksi fenomena, (Setiawan, 2014:245). Dari pendapat diatas dapat kita simpulkan bahwa literasi matematis adalah sebuah proses untuk memahami permasalah yang berhubungan dengan matematika dan dapat menerapkanya dalam kehidupan sehari-hari. 
Terdapat sejumlah variabel yang dapat menjadi determinan literasi siswa. Secara umum faktorfaktor tersebut dapat dikelompokkan dua kategori yaitu faktor dalam diri siswa (internal) dan faktor di luar diri siswa (faktor eksternal). Faktor internal dapat dipilah menjadi aspek kognitif seperti kemampuan intelektual, kemampuan numerik, dan kemampuan verbal; dan aspek nonkognitif seperti minat dan motivasi. Adapun faktor eksternal meliputi lingkungan keluarga, lingkungan sekolah, serta lingkungan media massa dan lingkungan sosial (Pusat Penilaian Pendidikan Balitbang Kemdikbud, 2013b).

\section{Tabel 1. Level Kemampuan Literasi Matematis}

\begin{tabular}{cl}
\hline Level & \multicolumn{1}{c}{ Deskripsi } \\
\hline 1 & $\begin{array}{l}\text { Menggunakan pengetahuan untuk menyelesaikan soal rutin, dan dapat } \\
\text { menyelesaikan masalah yang konteksnya umum. }\end{array}$ \\
\hline 2 & Menginterpretasikan masalah dan menyelesaikan dengan rumus \\
\hline 3 & $\begin{array}{l}\text { Melaksanakan prosedur dengan baik dalam menyelesaikan soal serta dapat } \\
\text { memilih strategi pemecahan masalah }\end{array}$ \\
\hline 4 & $\begin{array}{l}\text { Bekerja secara efektif dengan model dan dapat memilih serta mengintegrasikan } \\
\text { representasi yang berbeda, kemudian menghubungkannya dengan dunia nyata }\end{array}$ \\
\hline 5 & $\begin{array}{l}\text { Bekerja dengan model untuk situasi yang kompleks serta dapat menyelesaikan } \\
\text { masalah yang rumit }\end{array}$ \\
\hline 6 & $\begin{array}{l}\text { Menggunakan penalaran dalam menyelesaikan masalah matematis, dapat } \\
\text { membuat generalisasi, merumuskan serta mengkomunikasikan hasil temuannya }\end{array}$ \\
\hline & Sumber: Jumarnati (2009:69).
\end{tabular}

Pembelajaran berbasis masalah merupakan pembelajaran yang membebaskan siswa untuk memilih penelitiannya sendiri sehingga memungkinkan mereka untuk mengaitkannya dengan fenomena nyata dan membangun pemahaman dengan konsep yang mereka dapatkan dari fenomena tersebut( Putri, 2014:85). Pembelajaran ini juga melatih berbagai macam masalah yang ditimbulkan seiring dengan perkembangan jaman. Model pembelajaran berbasis masalah merupakan salah satu model pembelajaran yang menyajikan masalah kontekstual yang dapat merangsang kreativitas peserta didik untuk menemukan konsep dan memecahkan masalah dalam kehidupan sehari-hari, (Bahriah, 2015:15). Jadi dapat disimpulkan bahwa Pembelajaran berbasis masalah adalah pembelajaran yang menjadikan sebuah permasalahan nyata siswa sebagai sebuah proses pembelajaran.

Sanjaya (2008) mengemukakan enam langkah dalam pembelajaran dengan model pembelajaran berbasis masalah yaitu : (1) Menyadari masalah, adanya kesadaran terhadap keberadaan masalah yang harus dipecahkan ; (2) Merumuskan masalah, siswa dapat memanfaatkan pengetahuannya untuk mengkaji, memerinci dan menganalisis masalah 
sehingga pada akhirnya muncul rumusan masalah yang jelas, spesifik dan dapat dipecahkan ; (3) Merumuskan hipotesis, sebagai proses berpikir ilmiah yang merupakan perpaduan dari berpikir deduktif dan induktif. Kemampuan yang diharapkan dari siswa menentukan sebab akibat dari masalah yang akan diselesaikan sehingga siswa dapat menentukan berbagai kemungkinan penyelesaian masalah ; (4) mengumpulkan data, sebagai proses berpikir empiris, yaitu menentukan cara penyelesaian masalah sesuai dengan hipotesis yang diajukan harus sesuai dengan data yang ada. Proses berpikir ilmiah bukan berpikir imajinasi akan tetapi proses yang didasarkan pada pengalaman. Pada tahapan ini, siswa diharapkan memiliki kecakapan mengumpulkan dan memilah data, kemudian memetakan dan menyajikan dalam berbagai tampilan sehingga mudah dipahami; (5) Menguji hipotesis, dimana siswa menentukan hipotesis mana yang diterima dan mana yang ditolak. Siswa diharapkan memiliki kecakapan menelaah data dan sekaligus membahasnya untuk melihat hubungan dengan masalah yang dikaji; (6) Menentukan pilihan penyelesaian, siswa diharapkan memiliki kecakapan memilih alternatif penyelesaian (Maryuningsih, 2013:10).

Didalam pembelajaran berbasis masalah erat kaitanya dengan literasi matematis. Dapat kita analisa dari hubungan langkah pembelajaran berbasis masalah dengan level indikator literasi matematiks. Langkah pertama pembelajaran berbasis masalah yaitu menyadari masalah, didalam langkah ini siswa diminta untuk mengenal terlebih dahulu permasalahan yang dihadapi. Ini berkaitan dengan indikator level kemampuan literas matematiks yaitu menggunakan pengetahuan untuk menyelesaiakn soal rutin dan dapat menyelsaikan masalah umum. Langkah kedua merumuskan masalah, pada tahap ini siswa diminta untuk dapat merumuskan permasalahan yang dihadapi menjadi semuah rumusan masalah, hal ini juga berkaitan dengan level kedua indikator kemampuan literasi matematiks yaitu, menginterpretasikan masalah dan menyelesaikan denga rumus. Siswa dengan merumuskan sebuah masalah berati siswa dapat menginterpretasikan masalah dan dapat menjadikanya sebuah rumusan masalah.

Pada tahap merumuskan hipotesis, siswa diminta mampu menduga permasalahan yang terjadi dan mampu memperkirakan proses pemecahan masalahnya. Langkah ini berkaitan dengan siswa level kemampuan literasi matematika yaitu melaksanakan prosedur dengan baik dalam meyelesaikan soal serta dapat memilih strategi pemecahan masalah. Dalam merumuskan hipotesis siswa harus mampu melaksanakan prosedur secara sistematis dan menduga dan memilih bagaimana permasalahan tersebut dapat dipecahkan. Pada tahap mengumpulkan data, siswa berusaha untuk mencari informasi 
dari berbagai sumber informasi dan dengan berbagai cara. Pada tahap ini level kemampuan indikator literasi matematis yang keempat sangat berkaitan yaitu siswa dapat bekerja secara efektif dengan model dan dapat memilih serta mengintegrasikan representasi yang berbeda, kemudian menghubungkannya dengan dunia nyata. Dikarenakan siswa mengumpulkan data harus mampu bekerja secara efektif dan harus dapat mengintegrasikan representasi yang berbeda sehingga mereka dapat mengembangkan informasi dari sumber dan cara yang berbeda.

Pada tahap menguji hipotesis, siswa diminta untuk dapat menggunakan informasi untuk menguji permasalahan yang telah diduga. Hal ini berkaitan dengan level kelima kemampuan literasi matematika yaitu bekerja dengan model untuk situasi yang kompleks serta dapat menyelesaikan masalah yang rumit. Pada tahap menguji hipotesis siswa diminta untuk menggunakan informasi yang sudah ada dan mengujikanya secara komplekshingga siswa dapat menyelesaikan pemrasalahan yang rumit. Pada tahap menentukan pilihan penyelesaian, siswa diminta untuk menentukan pilihan untuk menyelesaikan permasalahan. Hal ini berkaitan dengan level keenam kemampuan literasi matematika yaitu menggunakan penalaran dalam menyelesaikan masalah matematis, dapat membuat generalisasi, merumuskan serta mengkomunikasikan hasil temuannya. Pada tahap memnetukan pilihan penyelesaian siswa menggunakan penelaran untuk menyelesaikan permasalahanya serta dapat mengambil sebuah kesimpulan secara generalisasi sehingga hasil temuan tersebut dapat di rumuskan dan dikomunikasikan.

Selain itu ketarkaitan literasi matematiks dalam pembeajaran berbasis masalah dapat dilihat dari karekateristik pembelajaran berbasis masalah dengan komponen kemampuan literasi matematika. Matrik keterkaitan karekateristik PBL terhadap komponen kemampuan literasi matematika dapat dilihat pada tabel dibawah ini:

Tabel 2. Matrik Keterkaitan Karekateristik Pembelajaran Berbasis Masalah terhadap Komponen Kemampuan Literasi Matematika

\begin{tabular}{cll}
\hline No & \multicolumn{1}{c}{$\begin{array}{c}\text { Karakteristik pembelajaran } \\
\text { berbasis masalah }\end{array}$} & $\begin{array}{c}\text { Komponen-komponen kemampuan } \\
\text { literasi matematika }\end{array}$ \\
\hline 1 & $\begin{array}{l}\text { Berangkat dari permasalahan yang ill } \\
\text { structured dan berdasarkan konteks } \\
\text { dunia (phenomenological exploration). }\end{array}$ & $\begin{array}{l}\text { Siswa mampu menyadari tantangan dan } \\
\text { memahami situasi masalah }\end{array}$ \\
\hline 2 & $\begin{array}{l}\text { Menggunakan setting kolaborasi dan } \\
\text { mempromosikan kontribusi siswa. }\end{array}$ & $\begin{array}{l}\text { Siswa mampu merencanakan pemecahan } \\
\text { masalah melalui diskusi dengan teman } \\
\text { sebaya }\end{array}$ \\
\hline 3 & $\begin{array}{l}\text { Adanay penyelidikanindividual dan } \\
\text { kelompok (Guided reinvention), }\end{array}$ & $\begin{array}{l}\text { Siswa mampu menyadari tantangan dan } \\
\text { memahami situasi masalah }\end{array}$ \\
\hline
\end{tabular}




\begin{tabular}{lll}
\hline & $\begin{array}{l}\text { pengumpulan informasi, dan } \\
\text { mengamati }\end{array}$ & \\
\hline 4 & $\begin{array}{l}\text { Adanay proses menalar, representasi, } \\
\text { dan matematisasi }\end{array}$ & $\begin{array}{l}\text { Siswa mampu mentransformasi masalah } \\
\text { dunia nyata kedalam model matematika } \\
\text { Siswa mampu melakukan representasi } \\
\text { objek dan situasi } \\
\text { Siswa mampu bernalar dan berpikir logis }\end{array}$ \\
& & $\begin{array}{l}\text { Adanya tahap mengembangkan dan } \\
\text { menyajikan } \begin{array}{l}\text { Siswa mampu mengkomunikasikan hasil } \\
\text { (mengkomunikasikan) }\end{array}\end{array}$ \\
\hline
\end{tabular}

Hal ini disadur oleh Istiandaru, 2015:9.

Berdasarkan tabel diatas dapat kita analisis yiaut karaktersitik PBL berangkat berangkat dari permasalahan yang ill structured dan berdasarkan konteks dunia (phenomenological exploration), dimana siswa belajar dari permasalah nyata yang terjadi dalam kehidupan sehari-hari. Sehingga dari masalah tersebut siswa mampu memahami dan belajar dari permasalahan. Hal ini sesuai dengan komponen dari literasi matematiks yang dituntut siswa untuk menyadari tantangan dan memahamis situasi masalah. Pada literasi matematis dituntut siswa untuk dapat mengetahui tantangan yang harus dihadapi dan siswa harus memahami situasi permasalahan agar bisa menyelesaikan permasalahan dan menjadikan permasalahan tersebut sebagai sebuah proses pembelajaran.

Karaktersitik pembelajaran berbasis masalah selanjutnya adalah menggunakan setting kolaborasi dan mempromosikan kontribusi siswa. Maksudnya adalah siswa diharapkan dapat menggunakan pemikiranya utuk berkerjasama dengan teman sebayanya serta dapat saling bertukar informasi mengenai masalah dan bagaimana proses pemecahanya. Siswa diharapkan mampu memberikan informasi terbaik yang diharapkan serta mampu menggabungkan informasi-informasi yang di dapat dari anggota lain. Hal ini sesuai dengan komponen literasi matematis yaitu siswa mampu merencanakan pemecahan masalah melalui diskusi dengan teman sebaya. Dalam proses ini siswa harus mampu merencanakan sebuah proses pemecahan masalah. Pada pembelajaran berbasis masalah salah satu karakteristiknya adalah adanya penyelidikan individual dan kelompok (guided reinvention). Siswa diharapkan mampu melakukan pencarian informasi yang berkaitan dengan materi agar dapat memecahan masalah. Pencarian informasi ini dapat dilakukan dengan berbagai cara baik secara individu maupun kelompok. Dan ini juga berkaitan dengan komponen literasi metematiks lainya adalah siswa mampu menyadari tantangan dan memahami situasi masalah. Siswa diminta untuk menyadari sebuah 
permasalah dan mencari informasi mengenai masalah tersebut sehingga siswa mampu untuk memahami permasalahan tersebut.

Didalam karakteristik pembelajaran berbasis masalah terjadinya proses menalar, representasi, dan matematisasi. Maksudnya adalalah dalam proses pembelajaran siswa dituntut untuk dapat mengambil sebuah kesimpulan, mengungkapakn bahasa matematika yang ditampilkan siswa sebagai model atau bentuk pengganti dari suatu situasi masalah yang digunakan untuk menemukan solusi dari masalah yang sedang dihadapinya sebagai hasil dari interpretasi pikirannya. Hal ini sesuai dengan komponen literasi matematika yaitu siswa diharapkan mampu mentransformasi masalah dunia nyata kedalam model matematika, melakukan representasi objek dan situasi dan siswa mampu bernalar dan berpikir logis. Selain itu karakteristik pembelajaran berbasis masalah adalah adanya tahap mengembangkan dan menyajikan hasil karya (mengkomunikasikan) sedangkan komponen literasi matematika ialah siswa mampu mengkomunikasikan hasil pemecahan masalah.

Dari penjelesan diatas dapat kita analisis bahwa pembelajaran berbasis masalah memiliki hubungan yang erat terhadap liiterasi. Oleh sebab itu sanagt dianjurkan kepada guru untuk dapat menerapkan pembelajaran berbasis masalah untuk meningkatkan kemampuan literasi matematika siswa.

\section{SIMPULAN}

Literasi matematika dalam pembelajaran berbasis masalah sangat erat kaitanya antara satu dengan yang lainya. Literasi matematika yang menjadikan pengetahuannya untuk dapat menyelesaikan dan mengkomnukasikan sebuah permasalah bersesuaian dengan proses pembelajaran berbasis masalah yang memuntut siswa untuk belajar dari sebuah permasalahan serta mneyelesaikan permasalahan tersebut.

\section{REFERENSI}

Aini, Indrie Noor. (2013). Meningkatkan Literasi Matematis Siswa melalui Pendekatan Keterampilan Proses Matematis (Studi Kuasi Eksperimen pada Siswa Madrasah Tsanawiyah). Tesis. Universitas Pendidikan Indonesia (UPI) Bandung. Tidak diterbitkan.

Badan Penelitian dan Pengembangan, Kemdikbud. (2013). Laporan Studi Kajian Peserta Didik pada Tingkat Dasar dan Menengah. Jakarta: Badan Penelitian dan Pengembangan. 
Bahriah, Evi Sapinatul. (2015). Peningkatan Literasi Sains Calon Guru Kimia Pada Aspek Konteks Aplikasi Dan Proses Sains. Jurnal EDUSAINS, 7 (1), 2015. h. 1117.

Fitri, Rahma, Helma, Hendra Syarifuddin. (2014). Penerapan Strategi The Firing Line Pada Pembelajaran Matematika Siswa Kelas XI IPS SMA Negeri 1 Batipuh. Jurnal Pendidikan Matematika : Part 2 Vol. 3 No. 1. h. 18-22.

Ibrahim dan Suparni. (2008). Strategi Pembelajaran Matematika. Yogyakarta: Universitas Islam Negeri (UIN) Sunan Kalijaga.

Istiandaru, Afit. Vita Istihapsari, dkk. Problem Based Learning (PBL) dengan Pendekatan Realistik-Saintifik dan Asesmen PISA untuk Meningkatkan Kemampuan Literasi Matematika. Jurnal Edumatica Volume 05 nomor 01, April 2015. ISSN: 20882175. h.1-11.

Jumarniati. (2009). Kemampuan Literasi Matematika dalam Menyelesaikan Masalah Turunan Fungsi Trigonometri. Jurnal Pedagogy Volume 1 Nomor 2. h. 66-75.

Kusumah, Yaya S. (2011). Literasi Matematis. Makalah disampaikan dalan seminar nasional Jurusan PMIPA FKIP Universitas Lampung Pada Tanggal 26 November 2011. Proseding ISBN 978-979-8150-32-8.

Maryuningsih,Yuyun. (2013). Penerapan Problem Base Learning dalam Pembelajaran Sebagai Upaya Membangun Kemandirian Belajar untuk Meningkatkan Keterampilan Kerja Ilmiah Danliterasi Sains Pada Mahasiswa. Jurnal Scientiae Educatia Volume 2 Edisi 1.

Organisation for Economic Co-operation and Development. (2015). PISA 2009 Assessment Framework, Key Compe-tences in Reading, Mathematic and Science.

Pisa Result diakses di https://www.oecd.org/pisa/pisa-2015-results-in-focus.pdf pada tanggal 01 Agustus 2017.

Puspendik. (2015). Hasil TIMSS 2015TIMSS 2015 Trend in International Mathematics and Science StudyTrend in International Mathematics and Science Study. Diagnosa Hasil untuk Perbaikan Perbaikan Mutu dan Peningkatan Peningkatan Capaian. Diakses pada http://puspendik.kemdikbud.go.id tanggal 28 Agustus 2017.

Putri, Amytia. (2014). Pengaruh Model Problem Based Learning Berbasis Potensi Lokal pada Pembelajaran Biologi terhadap Kemampuan Literasi Sains Siswa Kelas X SMA Negeri 1 Cepogo. Jurnal BIO-PEDAGOGI Volume 3, Nomor 2 ISSN: 22526897. h. 81-94.

Putriyani, Marina. (2014). Peningkatan Keaktifan dan Prestasi Belajar Matematika melalui Penerapan Pendekatan Open Ended Siswa Kelas VI Sekolah Dasar. EJurnal Dinas Pendidikan Kota Surabaya; Volume 6. ISSN : 2337-3253. h. 1-7

Sari, Rosalia Hera Novita. (2015). Literasi Matematika: Apa, Mengapa dan Bagaimana?, Seminar Nasional Matematika dan Pendidikan Matematika Uny 2015. ISBN. 978602-73403-0-5. h.713-720.

Setiawan, Harianto, dkk. (2014). Soal Matematika dalam PISA Kaitannya dengan Literasi Matematika Dan Keterampilan Berpikir Tingkat Tinggi. Prosiding Seminar Nasional Matematika, Universitas Jember, 19 November 2014. 244-25.

Sugandi, Milla Mustikawati. (2013). Penerapan Model Pembelajaran Osborn untuk Meningkatkan Literasi dan Disposisi Matematis Siswa SMP (Studi Eksperimen pada Siswa SMP di Kota Cimahi). Tesis. Universitas Pendidikan Indonesia (UPI. Bandung: Tidak diterbitkan.

Wardono, Ary Woro Kurniasih. (2015). Peningkatan Literasi Matematika Mahasiswa Melalui Pembelajaran Inovatif Realistik E-Learning Edmodo Bermuatan Karakter Cerdas Kreatif Mandiri. Jurnal Matematika Kreatif-Inovatif. Kreano 6 (1) (2015): 93-100. 